\title{
Personal Data Processing Within the Framework of Co-operation Between the Employer and the Trade Union in Individual Employment Matters
}

\author{
Submitted: 3.12.2020. Accepted: 15.04.2021
}

\begin{abstract}
The purpose of the paper is to analyse issues related to personal data processing within the framework of co-operation between the employer and trade unions in individual employment matters. The issues of personal data processing in collective relations are becoming more important especially due to lack of detailed legislative solutions, which results in the necessity to apply the general provisions of the GDPR as well as the latest changes to the Trade Unions Act. Pursuant to these changes, not only employees, but also persons performing gainful employment who are not employees can create and join trade unions as well as can be defended by the trade unions. The legislator frequently finds it difficult to adjust the protection of personal data to the specificity of collective relations, and the way in which the relationship between employers and trade unions is shaped in individual employment matters raises many questions in the context of personal data protection. The issue in question has not been explored in depth in the professional labour law literature. Thus, research on this subject is novel and justified from both the theoretical and the practical perspective. In the article, the formal-dogmatic method of research was used.
\end{abstract}

Keywords: personal data processing, collective relations, trade union, employer, individual employment matters, collective labour law.

1 Prof. Łukasz Pisarczyk - Faculty of Law and Administration, Warsaw University (Poland); e-mail: 1.pisarczyk@wpia.uw.edu.pl; ORCID: 0000-0001-9312-7489.

2 PhD Agata Miętek - Kozminski University (Poland); e-mail: amietek@kozminski.edu.pl; ORCID: 0000-0002-7708-1502. 


\section{Przetwarzanie danych osobowych w ramach współdziałania pracodawcy i związku zawodowego w indywidualnych sprawach pracowniczych}

\section{Streszczenie}

Celem niniejszej pracy jest analiza kwestii związanych z przetwarzaniem danych osobowych w ramach współpracy pracodawcy i związków zawodowych w indywidualnych sprawach pracowniczych. Kwestie przetwarzania danych osobowych w przypadku zbiorowych stosunków pracy stają się coraz ważniejsze zwłaszcza ze względu na brak szczegółowych rozwiązań legislacyjnych - co skutkuje koniecznością stosowania ogólnych przepisów RODO - a także ostatnich zmian w Ustawie o związkach zawodowych. Zgodnie z tymi zmianami nie tylko pracownicy, lecz również osoby niebędące pracownikami, które wykonują pracę zarobkową, mogą tworzyć związki zawodowe i wstępować do nich, jak również być przez nie chronieni. Ustawodawcy często trudno jest dostosować ochronę danych do specyfiki zbiorowych stosunków pracy, a sposób, w jaki w indywidualnych sprawach pracowniczych kształtuje się relacja między pracodawcami a związkami zawodowymi, budzi wiele wątpliwości co do ochrony danych osobowych. Przedmiotowa kwestia nie została dogłębnie zbadana $w$ fachowej literaturze dotyczącej prawa pracy. Dlatego też badanie tego tematu jest nowatorskie i uzasadnione z perspektywy zarówno teorii, jak i praktyki. W artykule wykorzystano formalno-dogmatyczną metodę badawczą.

Słowa kluczowe: przetwarzanie danych osobowych, zbiorowe stosunki pracy, związek zawodowy, pracodawca, indywidualne sprawy pracownicze, zbiorowe prawo pracy. 


\section{Introductory Remarks}

Trade unions represent and defend rights as well as trade- or profession-related and social interests of workers (Article 1 of the Trade Unions Act). Trade union activity covers the area of 1) collective rights and interests and 2) individual matters relating to or connected with performance of paid work. In terms of collective rights and interests, the trade unions generally represent all persons enjoying trade union rights, regardless of their trade union membership. In individual matters, the legislator - respecting the negative freedom of association - provides for representation of trade unions' members as well as persons who have requested such representation, as long as the union accepts the request. Representation in individual cases takes place at a company (workplace) level, which requires co-operation between the employer and the company (or inter-company) trade union. The effectiveness of the exercising of trade union rights in individual employment matters and the proper performance of the employer's duties in this respect requires processing of personal data of the persons represented by the trade unions. ${ }^{3}$ In the absence of detailed legislative solutions concerning the processing of personal data in relations between the employing entities and trade unions, the general provisions of the Regulation (EU) 2016/679 of the European Parliament and of the Council of 27 April 2016 on the Protection of Natural Persons with Regard to the Processing of Personal Data and on the Free Movement of Such Data, and Repealing Directive 95/46/EC (General Data Protection Regulation) ${ }^{4}$ will apply. ${ }^{5}$ The reference point for assessing what categories of personal data and to what extent this data may be processed within the framework of co-operation between an employer and a trade union in individual employment matters will therefore be, in the first place, the rules of personal data processing set out in Article 5 of the GDPR. With regard to specific categories of data, it will also be necessary to take into account Article 9 of GDPR (which regulates the processing of sensitive data)

3 J. Żołyński, Ochrona danych osobowych w zbiorowym prawie pracy-aspekt aksjologiczny i praktyczny, "Monitor Prawa Pracy" 2019, 12, p. 21; D. Dörre-Kolasa, Administrator danych osobowych w zbiorowym prawie zatrudnienia, "Studies on Labour Law and Social Policy" 2019, 4, p. 369.

4 Official Journal of the European Union L No. 119, p. 1, 'GDPR'.

5 A. Nerka, [in:] M. Sakowska-Baryła (ed.), Ogólne rozporządzenie o ochronie danych osobowych. Komentarz, Warszawa 2018, Legalis. 
and Article 10 (which regulates the processing of personal data concerning convictions and criminal offences). However, several questions arise as to whether and to what extent the rules stemming from the GDPR can be modified by the provisions of labour law.

\section{Individuals Benefiting from Trade Union Representation in Individual Cases}

In individual cases concerning performance of paid work, trade unions first and foremost represent the rights and interests of their members vis-à-vis the employer. The trade union's consent to this representation is not necessary as the trade union membership alone is a sufficient prerequisite. However, a trade union may also undertake to represent the rights and interests of a non-affiliated person against the employer if the person submits a relevant request and: (i) carries out paid work within the meaning of Article 1(1) of the Trade Unions Act; (ii) carries out paid work after retirement or a pension; (iii) is unemployed; (iv) is a volunteer, trainee or another person who personally performs unpaid work; (v) has been assigned to an employer for alternative civilian service; (vi) is an officer of the police, border guard, customs administration, penitentiary service or the State Fire Service or an employee of the Supreme Audit Office. The form of the request is not specified in the law, meaning that it may be submitted in any form, including orally. ${ }^{6}$ Pursuant to Article 30(2) of the Trade Unions Act, if a request to this effect is submitted, trade union representation becomes available after acceptance by a company trade union. ${ }^{7}$

\section{Scope of Co-operation with the Trade Unions in Individual Employment Matters}

Labour law does not contain a definition of an individual case in which there may be a need for co-operation between the employer and the trade union. With regard to employees, this issue is regulated in Article $23^{2}$ of the Labour Code, according to which the employer is obliged to co-operate in individual employment matters if the labour law provides for such co-operation. The concept of 'labour law provisions' includes not only the provisions of generally applicable laws, but also the

6 K.W. Baran, Komentarz do ustawy o zwiazkach zawodowych, [in:] idem (ed.), Zbiorowe prawo zatrudnienia. Komentarz, Warszawa 2019, LEX.

7 Z. Hajn, [in:] idem (ed.), Zbiorowe prawo pracy. Zarys systemu, Warszawa 2013, LEX. 
provisions of collective bargaining agreements and other collective agreements based on the law, the provisions of regulations and statutes which define the rights and obligations of the parties to an employment contract (Article $9 \S 1$ of the Labour Code). In consequence, beyond the generally applicable provisions that provide for an obligation to co-operate, such an obligation may also stem from autonomous acts. For instance, collective bargaining agreements may provide for an obligation to co-operate in other, non-statutory, individual cases (such as an obligation to consult with a trade union the employer's decision to impose a disciplinary penalty on an employee). The employer's obligation to co-operate with the trade union in individual cases can be either firm (and take the form of consent/objection) or consultative (an obligation to consult).

Examples of situations requiring co-operation regulated in the generally applicable provisions include: consultation on the intention to serve a notice of termination of an employment contract (Article 38 of the Labour Code), expressing consent to the termination of the employment relationship with employees whose status is linked to extra protection, including particularly trade union activists (Article 32 of the Trade Unions Act). As a rule, the statutory obligation to co-operate does not apply to workers who are not employees. The exception is the protection of the trade union activists, which has been extended to persons performing paid work who are not employees (Article 32 of the Trade Unions Act).

The employer has grounds for requesting information on representation of the employee/worker in every case where its co-operation with the trade union is mandated, regardless of whether the source of the obligation is a law or an autonomous act. In all other situations, where there is no legal basis for co-operation, such an obligation, and thus the employer's right to demand certain information about the represented person will not arise.

In structural terms, there may be three categories of co-operation procedures in which personal data is processed, the first two of which are directly based on generally applicable laws. The first category includes situations in which an employer requests information from a trade union as to whether a given person enjoys trade union protection. With regard to employees, the procedure under which the employer requests the transfer of their personal data is set out in Article 30(3) of the Trade Unions Act. It provides that in individual cases related to an employment relationship in which the provisions of the labour law oblige the employer to co-operate with a company trade union, before taking action, the employer is required to ask the union if the employee enjoys its protection. Failure to provide the information within 5 days of the date of request receipt by the trade union releases the employer from the obligation to co-operate in matters concerning that employee. The second category includes those procedures in which the employer shares their 
personal data with the trade union, including a justification for the intention to serve them a notice of employment contract termination or to terminate an employment contract without notice. The third category includes situations in which the trade union or the employer shares personal data of employees and other persons on grounds other than the generally applicable laws (e.g. under autonomous acts or agreements).

\section{A Trade Union as a Personal Data Controller}

According to Article 4(7) of the GDPR, a controller is a natural or legal person, public authority, agency or other body which, alone or jointly with others, determines the purposes and means of the personal data processing; where the purposes and means of such processing are determined by Union or Member State law, ${ }^{8}$ the controller or the specific criteria for its nomination may be provided for by Union or Member State law. The definition of a controller includes three elements: one person-related, one control-related and one fundamental. The essence of the person-related element is that the recognition of an organisational unit as a personal data controller does not depend on its organisational and legal form, including on whether it has legal personality. ${ }^{9}$ This will be important from the perspective of this paper as collective labour law is characterised by a great variety of trade union structures, not all of which have legal personality. The control-related element of the personal data controller definition means that the function may be exercised independently or jointly with others. The essence of the fundamental element is to determine the purposes and means of processing personal data, which distinguishes a personal data controller from other entities. The assessment of this element in the opinion of the Working Party on the Protection of Individuals with Regard to the Processing of Personal Data (Article 291/2020 $0^{10}$ ) distinguishes three categories of situations in which the purposes and means of processing personal data will be determined: (i) control based on explicit legal powers - the controller is designated directly by law, either by direct designation of a controller or by imposing specific obligations which require personal data processing; (ii) control based on

8 With regard to the dispute as to whether the GDPR applies to personal data processing for the purpose of fulfilling a statutory obligation, see further discussion in: A. Sobczyk, RODO. Rozproszona wtadza publiczna, Kraków 2019, pp. 65-67; D. Dörre-Kolasa, op. cit., pp. 367 et seq. and the literature indicated there.

9 D. Dörre-Kolasa, op. cit., p. 371.

10 The Opinion of the Working Party on the Protection of Individuals with Regard to the Processing of Personal Data on the Concepts of "Controller" and "Processor", adopted on 16 February 2010, 00264/10/PL, WP 169, p. 5. 
implicit competence - determination of the purposes and means of personal data processing and thus the controller designation results from common legal provisions or established practice in various fields (e.g. labour law); (iii) control based on actual influence - applies when the controller's function is assigned on the basis of an assessment of factual circumstances (e.g. an assessment of contractual relations between the parties involved).

Analysing the above in the context of this study, first of all, it should be noted that from the GDPR perspective, a trade union may act as a personal data controller regardless of its organisational and legal form if, independently or jointly with others, it determines the purposes and means of the personal data processing on the basis of the law, established practice or actual influence. This is important because pursuant to Article 9 in conjunction with Article 13(7) of the Trade Unions Act, the organisational structures of trade unions are freely determined by their charters and resolutions, with indication of those organisational units of the trade union that have legal personality.

The fundamental element (i.e. the determination of who will determine the purposes and manner of data processing) on the part of the trade union has not been structured in the same way with regard to all individual employment matters.

When it comes to individual cases requiring co-operation on the basis of generally applicable laws, it is the legal provision providing for the obligation to co-operate that defines the organisational and legal form of the trade union unit to which a specific scope of rights and obligations is assigned, the performance of which involves various types of personal data processing. ${ }^{11}$ With regard to a vast majority of categories of individual cases specified in the generally applicable laws, the right to co-operate with the employer (and thus to process personal data) has been granted to company trade unions. ${ }^{12}$ The company trade union is a trade union structure covering the entire enterprise. ${ }^{13} \mathrm{~A}$ company trade union may be either an independent trade union operating exclusively in a given enterprise or an organisational unit of a nationwide trade union. However, the company trade union must meet certain formal requirements stemming from the law (a required number of members, providing information to the employer). The rights of a company trade union

11 D. Dörre-Kolasa, op. cit., p. 375.

12 This is consistent with the scope of activity of a company trade union, which, pursuant to Article 26(1) of the Act of 23 May 1991 on Trade Unions, includes particularly taking a position on individual employment matters within the scope regulated by the labour law and on individual matters of persons working for pay within the scope related to the performance of such work.

13 A. Reda-Ciszewska, [in:] P. Czarnecki, P. Grzebyk, A. Reda-Ciszewska, B. Surdykowska, Ustawa o zwiazkach zawodowych. Komentarz praktyczny z orzecznictwem, Warszawa 2019, Legalis; judgment of the Supreme Court of 26 January 2011, Ref. No. I PK 144/10. 
may also be exercised by an inter-company trade union organisation (Article 34 of the Trade Unions Act).

Some of statutory procedures are not reserved for a company trade union, which means that depending on the nature of an individual case, the personal data controller may be not a company trade union but another trade union entity, i.e. a trade union operating at the level of the workplace, but not having the status of a company trade union; a trade union operating at a level lower than the workplace (e.g. in a branch) or at a level higher than the workplace. For instance, in the case of unpaid leave referred to in Article 25(1) of the Trade Unions Act, a request for leave may be submitted by a body that is entitled to do so under the trade union charter, and in which the employee is to perform their function..$^{14}$ With regard to procedures contained in autonomous acts, which do not provide for the obligation to co-operate with a company trade union, the act should specify the trade union entity entitled to receive and provide information on an individual employee case. In the absence of such an indication, the relevant trade union entity should be indicated taking into account the type of autonomous act in question and the manner in which it is created. As regards collective agreements and autonomous acts which has been introduced in agreement with the trade union entity, this entity will be competent to receive and provide information on the individual employee case. In the case of other autonomous acts stemming from Article 9 of the Labour Code (i.e. regulations and statutes defining the rights and obligations of the parties to the employment relationship), which are not created in agreement with the trade union entity, there are no legal grounds for granting the employer the right to independently introduce provisions imposing an obligation to co-operate if such an obligation does not result from generally applicable regulations, and at the same time, there is no consent of the trade union entity to be covered by such an obligation.

When processing data within the framework of co-operation between the trade union entity and the employer in individual employment matters, the trade union entity will be the controller, but so will be the employing entity.

Persons in the organisational structure of the employer and the trade union entity who process the personal data of employed persons within the scope of their duties must have appropriate authorisation, stemming from the generally applicable law or from a separate authorisation granted by the authorised entity.

14 For more details, see the Regulation of the Polish Council of Ministers of 3 December 2018 on the procedure for granting unpaid leave to an employee elected to perform a trade union function outside his or her workplace and the procedure to be followed in the event of expiry of the mandate of an employee elected to perform a trade union function taking unpaid leave (Journal of Laws of 2018, item 2358). 


\section{Obtaining Information on Persons Covered by Trade Union Protection}

The condition of the employer's co-operation with the trade union is to establish that the person who is to be affected by a specific action (e.g. termination of employment) is represented by the trade union in question (i.e. if its member or the union has undertaken such representation). This stage can be described as the identification stage. It is important because of the consequences that may arise from providing the employer with information about being under trade union protection (e.g. fear of reprisal from the employer). Therefore, the issue of the manner in which the information about the represented persons should be obtained has proved to be very controversial. For some time, the Supreme Court represented a position that the employer may request a list of all represented persons. ${ }^{15}$ Ultimately, due to lack of a clear legal basis for such request, this interpretation was challenged. ${ }^{16}$ It was expected that the employer would return with a question in each matter that required co-operation. The legislator confirmed this interpretation when amending the Trade Unions Act. Pursuant to Article 30(3) of the amended Trade Unions Act, in individual cases related to an employment relationship, in which the provisions of the labour law oblige the employer to co-operate with a company trade union before taking action, the employer is required to ask the union for information on whether the employee enjoys its protection.

The employer is obliged to address the company trade union 'before taking action,' which means that it is necessary to ask for information in each specific case and not collectively in relation to all employees. However, there are no reasons why a question should not concern several specific employees if the actions that the employer intends to take concern a group rather than an individual employee

15 Judgment of the Supreme Court of 7 May 2007, Ref. No. II PK 305/06; of 10 October 2002, Ref. No. I PKN 529/01; of 18 October 2005, Ref. No. II PK 90/05.

16 Judgement of the Supreme Court judgment of 21 April 1999, Ref. No. I PKN 36/99; Supreme Administrative Court's judgment of 18 December 2014, Ref. No. I OSK 900/13; Supreme Court's judgment of 7 May 2017, Ref. No. II PK 108/16). On 21 November 2012, the Supreme Court issued a resolution in accordance with which the failure of a company trade union to provide information about all employees benefiting from its representation, requested by the employer without a substantial reason, does not release the employer from the obligation to cooperate with that union in individual cases related to employment relationship (Ref. No. III PZP 6/12). In the justification to a resolution, the Supreme Court stated, among others, that the adoption of a different interpretation would raise a question about its compliance with EU regulations regarding personal data protection (see also: E. Podgórska-Rakiel, Ochrona danych osobowych w odniesieniu do przynależności zwiazkowej, "Gdańsk Legal Studies - Review of Jurisprudence" 2010, 2, p. 201; A. Wypych-Żywicka, Nieudzielenie przez zakładowa organizację związkowq informacji o pracownikach korzystajacych z jej obrony uzasadnione ochrona danych osobowych, "Gdańsk Legal Studies - Review of Jurisprudence" 2012, 3, p. 93. 
(however, it will be a sum of several individual questions). If there are several company trade unions in a workplace, then the employer should contact each of them as part of the identification stage until they receive confirmation of the representation or confirmation of the fact that no trade union offers representation to that employee. As part of the identification stage, the employer is entitled to ask whether a particular employee enjoys trade union representation and not to ask about their union membership. A question as to an employee's trade union membership will go beyond the purpose of personal data processing, as such knowledge is irrelevant for the purposes of obtaining knowledge about trade union representation. ${ }^{17}$ It seems, however, that the question about trade union representation as such (although not explicitly mentioned in Article 9 of the GDPR) should also be regarded as a question about sensitive data. Indeed, if information about the membership constitutes sensitive data pursuant to Article 9 of the GDPR, and the specific nature of data considered sensitive manifests itself, inter alia, in that its disclosure gives rise to risks of discrimination and other undesirable behaviour towards the employee, then if the representation is granted to a non-member, these risks may also occur. ${ }^{18}$

As part of the identification phase, the employer is neither obliged nor entitled to indicate the type of procedure in which the obtained data will be used. However, there are doubts as to whether the employer must contact the trade union if in the course of its activities the employer has obtained, in compliance with the law, data necessary to complete the identification stage (e.g. in connection with the payment of the membership fee for a given employee on the basis of a request from a trade union and the employee's consent). ${ }^{19}$ The issue is not obvious, only because different persons may be authorised by their employer to process data in particular individual cases. In such a case, it should be assumed that although it is not permissible to transfer data between persons who are not authorised to process data in a given procedure, there are no obstacles for the employer to transfer such data (e.g. when asking for preparation of the representation on termination of the employment contract, the employer informs the person that an employee in question is under trade union protection, even if information on the protection was acquired by the employer in a procedure within which the person preparing the termination notice is not authorised).

17 D. Dörre-Kolasa, op. cit., p. 377; A. Wypych-Żywicka, op. cit., p. 95.

18 Similarly: E. Podgórska-Rakiel, op. cit., p. 207 (the view expressed under the previous legal regime, but still valid).

19 As in, among others, the judgment of the Supreme Court of 10 March 2008, Ref. No. III PK80/07; of 26 March 2019, Ref. No. I PK 75/18. A different opinion was expressed in: D. Dörre-Kolasa, op. cit., p. 382. 
The rules of identification were created with the intention of ensuring effective protection of employees. The current model undoubtedly provides a higher level of protection than the previous mechanism, in which the employer was provided with the list of employees represented by the trade union. However, the current regulation still has certain weaknesses. The employer, as a rule, enquires with all company trade unions if they represent a particular employee. It is true that the employer does not provide information on what action they intend to take, but the vast majority of cases concern the dismissal of an employee or a proposed deterioration of working conditions. In effect, all trade unions receive information that may be taken to mean that the employee is about to be dismissed or that the employee's working conditions or pay will be affected. One may wonder if such interference with the employee's privacy is necessary. A better solution would be for the employee to notify the employer with regard to being represented by a trade union if that is, in fact, the case. ${ }^{20}$

\section{Processing of Personal Data Within Particular Procedures}

After the positive completion of the identification stage and confirmation that the company trade union representation covers the employee in relation to whom the employer intends to take action, the employer will provide the trade union with the information about the intended course of action as well as with other data necessary to proceed in a given case. In view of the procedures regulated by the generally applicable law, in which co-operation between the employer and the trade union will take place in individual matters, it is possible to indicate certain (typical, in a sense) categories of personal data subject to processing. These are data common for a particular procedure (e.g. allowing for the identification of a person affected by the procedure) and data specific to a particular case (e.g. reasons justifying the termination of an employment relationship with a particular employee). The basis for the data processing consists in the legal provisions regulating particular procedures and determining the scope of the transferred data.

It seems that the most typical (the most common) category of data subject to processing is personal data concerning improper performance of work by the employee as well as concerning improper behaviour of the employee. The employer is obliged to transfer this data to the trade union entity as part of the consultation procedure in connection with termination of the employment contract upon notice

20 See: J. Skoczyński, Uzyskiwanie przez pracodawcę informacji o pracownikach podlegających ochronie zwiazkowej w indywidualnych sprawach pracowniczych, "Monitor Prawa Pracy" 2012, 12. 
(Article 38 of the Labour Code), termination of the employment contract without notice (Article 52 \$1(1) in conjunction with Article $52 \S 3$ of the Labour Code), a unilateral alteration of conditions of work and pay (Article $42 \S 1$ in conjunction with Article 38 of the Labour Code) or review of an employee's objection to a disciplinary penalty (Article $112 \S 1$ of the Labour Code) if the improper performance of work or the improper behaviour of the employee constitutes reasons for the termination of the employment contract or imposition of a penalty.

Committing of a crime by the employee, disclosed in the representation of the employer on termination of the employment contract, can also constitute a reason for termination of the employment contract without notice due to the fault of the employee (Article $52 \S 1(2)$ in conjunction with Article $52 \S 3$ of the Labour Code).

Sensitive data that may be processed within the framework of co-operation between the employer and the trade union in individual employment matters includes particularly data concerning health, which can be disclosed with regard to the intention to terminate an employment contract without notice due to the employee's long-term incapacity as a result of an illness (Article $53 \S 1$ in conjunction with Article $53 \S 4$ of the Labour Code).

Other sensitive data that may be processed within the framework of co-operation between the employer and the trade union includes data revealing the political opinions and religious or philosophical beliefs of the employee. The data in question may be disclosed in the procedure of termination of the employment contract upon notice or without notice due to reasons on the part of the employee (Article 38 or Art $52 \S 1(1)$ in conjunction with Article $52 \S 3$ of the Labour Code), for instance, if the employment contract is terminated due to behaviour of the employee that consists in disclosing their political opinions or religious, or philosophical beliefs resulting in an unacceptable or aggressive attitude towards other employees.

Finally, data on employment conditions may be processed during the co-operation between the employer and the trade union, e.g. in the consultation procedure for the alteration of work and pay conditions (Article $42 \S 1$ of the Labour Code in conjunction with Article 38 of the Labour Code).

Processing of personal data is different in the case of trade union activists exercising their special rights. These entitlements include: special protection against employment termination (Article 32 of the Trade Unions Act); so-called trade union job (Article 31 of the Trade Unions Act); unpaid leave to perform trade union functions or temporary release from the obligation to perform work (Article 25 of the Trade Unions Act). These rights are vested in elected trade union members (and in the case of the first two instances, in company trade union members) once they have met certain statutory requirements. This means that in the above cases, the transfer of personal data will take place at the initiative of the trade unions in order 
to facilitate the exercise of specific rights by the trade union and the data subject, in accordance with Article 9(2)(b) of the GDPR. The exercise of specific rights must be preceded by the fulfilment of a legal obligation (i.e. confirmation that the person concerned has a specific right). For instance, under Article $32(9)^{2}$ of the Trade Unions Act, the board of a company trade union or its founding committee is obliged to give the employer a list of its members subject to protection together with their periods of protection.

As regards the scope of the data to be provided related to trade union activists exercising their special rights, this will vary from procedure to procedure and will include the following data: a specific position or function and term of office. Some doubts may arise in the case of release from work to perform ad hoc activities referred to in Article 25(5) - with regard to employees - and Article 25(6) - with regard to persons working for pay other than employees - of the Trade Unions Act. As per those articles, in a request for release from work to perform ad hoc activities, additional personal data is frequently processed, which raises the question of whether such a far-reaching solution is actually necessary in the context of Article 5 of the GDPR and the purpose of release from work to perform ad hoc activities. Instead, the labour law could provide for a maximum number of days to be used without the necessity to disclose the purpose of a specific release.

When assessing the above-mentioned typical data subject to processing within particular procedures of co-operation between the employer and the trade union entity from the perspective of provisions of the GDPR, it should be noted that in most cases, ordinary personal data will be disclosed.

Depending on the case, information disclosed within the framework of co-operation between the employer and the trade union in individual employment matters may include sensitive data within the meaning of Article 9(1) of the GDPR. The special nature of such data is manifested, inter alia, in the fact that its disclosure poses risks in the form of discrimination, as explicitly mentioned in Recital 71 of the GDPR with respect to trade union membership. ${ }^{21}$ In particular, sensitive data will be disclosed within procedures aiming at termination of the employment contract or the civil law contract.

Finally, in exceptional cases, special categories of data will be processed. This primarily relates to data on the criminal record of the employee/worker.

21 M. Kuba, [in:] E. Bielak-Jomaa, D. Lubasz (eds.), RODO. Ogólne rozporządzenie o ochronie danych. Komentarz, Warszawa 2018, LEX; D. Dörre-Kolasa, op. cit., p. 376; P. Fajgielski, Komentarz do rozporzadzenia nr 2016/679 w sprawie ochrony osób fizycznych $w$ zwiąku z przetwarzaniem danych osobowych $i$ w sprawie swobodnego przeptywu takich danych oraz uchylenia dyrektywy 95/46/WE (ogólne rozporządzenie o ochronie danych), [in:] idem, Ogólne rozporządzenie o ochronie danych. Ustawa o ochronie danych osobowych. Komentarz, Warszawa 2018, published, LEX. 
Depending on the category of data subject to disclosure within particular procedures, different rules of processing may apply. Ordinary personal data will be processed pursuant to general rules stemming from Article 5 of the GDPR. According to that Article, the following rules must be complied with when processing personal data (the employer must be able to demonstrate compliance): (i) the principle of lawfulness (processing is lawful only if one of the conditions set out in Article 6 of the GDPR is fulfilled ${ }^{22}$ ); (ii) the principle of accuracy and transparency of information and communications to the data subject - to be concise, easily accessible and understandable; ${ }^{23}$ (iii) the principle of purpose limitation - data may be collected for specific, clear and legitimate purposes; (iv) the principle of data minimisation/adequacy - only such data that is necessary for the purposes for which it is processed may be collected; (v) the principle of accuracy - data processed shall be accurate and, where necessary, updated; (vi) the principle of storage limitation - data may be processed only for the time necessary for the purposes for which it has been collected; (vii) the principle of integrity and confidentiality - data must be processed in a manner that ensures its adequate security.

Due to the specific nature of the data, its processing requires certain higher standards. Namely, it is prohibited to process it without the express consent of the data subject unless one of the conditions indicated in Article 9(2) of the GDPR is met. In particular, according to Article 9(2)(b) of the GDPR, the consent of the data subject is not required if the processing is necessary for the purposes of carrying out the obligations and exercising the specific rights of the controller or of the data subject in the field of employment, social security and social protection law in so far as it is authorised by the Union law or by the law of a Member State, or by a collective agreement under the law of a Member State providing for adequate safeguards for the fundamental rights and interests of the data subject.

In this context, the question must be asked whether the trade union representation as such, either by virtue of trade union membership or a non-associated person's eligibility for representation, can be regarded as implicit consent to the processing of other personal data by the trade union. It seems that this will be the case in those situations where the obligation to co-operate results from generally applicable laws or from a collective agreement. In all other instances, it will be required to obtain explicit consent to personal data processing. In particular, such a requirement may arise from Article 9(2)(d) of the GDPR, according to which the personal data of the members or former members of a union or persons who have regular

22 See: A. Sobczyk, op. cit., pp. 142-186.
23 J. Żołyński, op. cit., p. 22. 
contacts with the union in relation to its purposes may be disclosed outside the trade union only with the data subjects' consent.

As indicated above, the processing of sensitive personal data does not require the data subject's consent if the processing is necessary for the fulfilment of the obligations and the exercise of specific rights by the controller or the data subject in the field of employment, social security and social protection law, and this is permitted by a collective agreement concluded under the law of a Member State, which provides for the adequate protection of the fundamental rights and interests of the data subject. The above regulation may raise doubts concerning collective agreements other than collective bargaining agreements and particularly the requirement of 'being based on a statutory act' (Article $9 \S 1$ of the Labour Code). The GDPR does not contain the requirement of 'being based on a statutory act' but it does require general authorisation provided for in the law of a Member State, which could indicate that a broader interpretation is admissible, i.e. being based on a specific statutory provision or, in the absence of such a provision, authorisation that may be construed on the basis of the regulation as a whole. ${ }^{24}$ It seems, however, that due to the nature of personal data to be processed (sensitive data), the separate consent of the data subject will be required in each case when the basis for processing will be an agreement, which will not be considered collective agreements in the sense of Article 9 of the Labour Code.

Finally, if the reason for the termination of the employment contract is a criminal offence committed by the employee, then the procedure of co-operation with the trade union subject may involve the processing of data relating to convictions, which, according to Article 10 of the GDPR, may only be processed under the supervision of public authorities or if the processing is permitted by the Union law or by the law of a Member State providing for adequate safeguards for the rights and freedoms of data subjects. In this case, the basis for processing will be Article $52 \S 1(2)$ of the Labour Code in conjunction with Article $52 \S 3$ of the Labour Code.

\section{Conclusions}

The way in which the relationship between employers and trade unions is shaped in individual employment matters raises a number of questions in the context of personal data protection. The legislator frequently finds it difficult to adjust the

24 This position is also presented by the Supreme Court in relation to the requirement of 'being based on a statutory act' when interpreting Article $9 \$ 1$ of the Labour Code (see the judgment of the Supreme Court of 9 July 2015, Ref. No. I PK216/14; the judgment of the Supreme Court of 22 July 2015, Ref. No. I PK254/14). 
protection of personal data to the specificity of collective relations. One of the key issues concerns the creation of an appropriate mechanism for the employer to obtain information as to whether specific employees enjoy trade union protection. There was a need for a cautious approach in order to avoid exposing employees to unfavourable actions on the part of the employer. The current regulation protects employees in this regard, even though certain issues are still debatable. On the other hand, from the employers' perspective, the procedure is considered complex and complicated. The second important area is the provision of information to trade unions necessary to take a position on issues such as an opinion on the intention to dismiss an employee. The provision of data in this regard is necessary for the performance of trade union functions. It is predicated upon the decision of an employee who is a member of a trade union or requests trade union representation. Finally, there are numerous detailed issues that should be resolved in the course of the functioning of the provisions, given that they are still a relatively new addition to the Polish legal system. ${ }^{25}$

\section{Bibliography}

Baran K.W., Komentarz do ustawy o zwiazkach zawodowych, [in:] K.W. Baran (ed.), Zbiorowe prawo zatrudnienia. Komentarz, Warszawa 2019.

Dörre-Kolasa D., Administrator danych osobowych w zbiorowym prawie zatrudnienia, "Studies on Labour Law and Social Policy" 2019, 4.

Fajgielski P., Komentarz do rozporządzenia nr 2016/679 w sprawie ochrony osób fizycznych $w$ zwiqzk $z$ przetwarzaniem danych osobowych $i$ w sprawie swobodnego przeptywu takich danych oraz uchylenia dyrektywy 95/46/WE (ogólne rozporządzenie o ochronie danych), [in:] P. Fajgielski, Ogólne rozporządzenie o ochronie danych. Ustawa o ochronie danych osobowych. Komentarz, Warszawa 2018, LEX.

Hajn Z. (ed.), Zbiorowe prawo pracy. Zarys systemu, Warszawa 2013, LEX.

Kuba M., [in:] E. Bielak-Jomaa, D. Lubasz (eds.), RODO. Ogólne rozporządzenie o ochronie danych. Komentarz, Warszawa 2018, LEX.

Nerka A., [in:] M. Sakowska-Baryła (ed.), Ogólne rozporządzenie o ochronie danych osobowych. Komentarz, Warszawa 2018, Legalis.

Opinia Grupy Roboczej ds. Ochrony Danych Osobowych w sprawie pojęć "administrator danych" $i$ "przetwarzajacy", adopted on 16 February 2010, 00264/10/PL, WP 169, p. 5.

Podgórska-Rakiel E., Ochrona danych osobowych w odniesieniu do przynależności zwiazkowej, "Gdańskie Studia Prawnicze - Przegląd Orzecznictwa" 2010, 2.

25 Proofreading financed under DIALOG, No. 0227/2018 - a Programme of the Polish Ministry of Science and Higher Education. 


\section{4}

Reda-Ciszewska A., [in:] P. Czarnecki, P. Grzebyk, A. Reda-Ciszewska, B. Surdykowska,

Ustawa o zwiazkach zawodowych. Komentarz praktyczny z orzecznictwem, Warszawa 2019, Legalis.

Skoczyński J., Uzyskiwanie przez pracodawcę informacji o pracownikach podlegających ochronie zwiazkowej w indywidualnych sprawach pracowniczych , „Monitor Prawa Pracy” 2012, 12.

Sobczyk A., RODO. Rozproszona władza publiczna, Kraków 2019.

Wypych-Żywicka A., Nieudzielenie przez zakładowa organizację zwiazkowa informacji o pracownikach korzystających z jej obrony uzasadnione ochrona danych osobowych, "Gdańskie Studia Prawnicze - Przegląd Orzecznictwa" 2012, 3.

Żołyński J., Ochrona danych osobowych w zbiorowym prawie pracy - aspekt aksjologiczny i praktyczny, „Monitor Prawa Pracy” 2019, 12. 